\title{
EFFECT OF LIMING AND FERTILIZER APPLICATION IN HEMIC AND SAPRIC OF TROPICAL PEAT: PHOSPHORUS MINERALIZATION, INFRA-RED SPECTROSCOPY AND MICROSCOPY
}

\author{
${ }^{1}$ Ameera Abdul Reeza, ${ }^{1}$ Aminuddin Hussin, \\ ${ }^{1}$ Ahmad Husni Mohd Hanif and ${ }^{2}$ Mohd Aspollah Md. Sukari \\ ${ }^{1}$ Department of Land Management, Faculty of Agriculture \\ ${ }^{2}$ Department of Chemistry, Faculty of Science \\ Universiti Putra Malaysia, 43400, Serdang, Selangor, Malaysia
}

Received 2013-12-24; Received 2014-01-30; Accepted 2014-03-31

\begin{abstract}
This study was conducted to investigate the changes in nutrient level $\mathrm{P}$ as well as in the structural and functional groups upon the decomposition of Hemic and Sapric peat material due to application of lime and fertilizers. The peat materials were left to decompose for 8 weeks under laboratory incubation and samples were taken for the determination of extractable P at 1 week interval. At 8 weeks, samples were sent for FTIR and SEM analysis. Although both types of peat material exhibit similar patterns in the mineralization of phosphorus, however, the amount of extractable phosphorus between Hemic and Sapric during the decomposition process differed. Addition of fertilizer (T3) resulted in a significantly large increase in extractable P compared to T1 and T2 but the effect was temporal as the extractable P declined throughout the incubation period. Sapric material displayed more absorption bands from the FTIR spectral analysis compared to Hemic although there were few similarities between the bands produced. Application of fertilizer in T3 caused the peaks that were similar with other treatments became weaker and different functional groups were shown at lower frequencies. Images from SEM showed that addition of lime and fertilizers caused the collapsing and degradation of the plant cell structures in the organic materials of the peat justifying the process of decomposition had occurred. Hemic and Sapric peat material showed some similarities as well as differences in extractable P, plant cell structures and spectral bands upon the application of lime and fertilizers.
\end{abstract}

Keywords: Hemic, Sapric, Extractable P, Lime, Fertilizer, FTIR, SEM

\section{INTRODUCTION}

In Malaysia, there are as much as 2.4 million hectares of peat where major portions of the hectarage of about 1.5 million hectares are found in Sarawak alone. Organic soils such as peat contain more than $65 \%$ organic materials that are mainly derived from plants. There have been conflicting reports that the organic matter comprising peat may act as a storehouse for plant nutrients (Lickacz and Penny, 2001; Lewandowski, 2002) but due to the imbalance nutrient content, the fertility of the peat soil is often being questioned and thus pose challenges for agronomists and farmers to overcome the difficulties in cropping on organic soils (Gurmit et al., 1987; Tayeb, 2005).

Despite the perception by many quarters that peat soils are nutrient-poor, however there have been increasing amount of peat lands being reclaimed for Corresponding Author: Ameera Abdul Reeza, Department of Land Management, Faculty of Agriculture, Universiti Putra Malaysia, 43400, Serdang, Selangor, Malaysia 
agricultural activities (Strack, 2008). This has led to the rising attention in nutrient management as to achieve optimum produce in these organic soils. Numerous researches on the study of Phosphorus (P) as one of the most important macronutrient in plants have been reported. However, much of these research efforts are documented in bogs, fens, sedges and mires of the temperate peat (Verhoeven and Arts, 1987; Yli-Halla and Lumme, 1987; Verhoeven et al., 1990; Jordan et al., 2007) while little is known regarding its behaviour in tropical peat.

In order for agriculture to commence in peat soils, it is prerequisite to add lime and fertilizer as to alleviate the high acidity and to correct the imbalance nutritional disorder (Andriesse, 1988). However, previous reports by Yli-Halla and Lumme (1987) discovered that liming may reduce the solubility and thus the availability of $\mathrm{P}$ in peat soils. Also, as a consequence of liming the fertilization effect can also be reduced. Although liming can stimulate mineralization of organic $P$ releasing inorganic $\mathrm{P}$, however it can also cause precipitation of insoluble calcium phosphates that reduces the availability of $\mathrm{P}$ at high $\mathrm{pH}$ values (Haynes, 1982).

It is important to note that in understanding the nutrient dynamics in peat soils, it is pertinent to identify the factors that influencing the inherent fertility of peat. According to Tayeb (2005), one of the influential factors is the nature and types of peat which refers to the degree of decomposition of the peat (Lim et al., 2012). While much effort has been done in understanding the changes in P levels upon mineralization in peat soil based on the different types of the above-ground vegetation in temperate peats, there have been very limited studies on the mineralization of phosphorus in tropical peat particularly emphasizing on the types of peat material.

Aside from observing the changes occurring in peat on nutrient-release basis, the application of Fourier Transform Infrared Spectroscopy (FTIR) has been able provide more in-depth information on the process occurring in these organic matters without destructing the sample (Haberhaeur et al., 1998). The use of FTIR served as an important tool in providing information on the functional groups present in the organic matter and thus enabling to verify the presence of principal classes of organic compounds such as cellulose, lignins, lipids and so on. Such information is useful especially in the aspect of organic matter decomposition as to justify the presence or absence of a compound attributed to their functional groups due to the mineralization process. Also, the use of Scanning Electron Microscopy (SEM) can provide additional informational on the structural component of the organic materials comprising peat.
Being an organic matter that constantly undergoing changes due to their dynamic nature, the SEM can be of a useful tool in observing the structural changes affecting the peat material as a result of management practices. However, they are very few reported studies on microscopic features in organic soils especially emphasizing on tropical peat.

Thus, the objectives of this study were to investigate the changes on the level of extractable $\mathrm{P}$ as well as in spectral and structural aspect from FTIR and SEM attributed to the mineralization of Hemic and Sapric peat material upon addition of lime and fertilizer.

\section{MATERIALS AND METHODS}

\subsection{Materials}

\subsubsection{Soil Sampling and Preparation}

Peat samples were collected from a secondary peat forest of oligotrophic in nature (nutrient-poor) located at Kampung Kundang, Batu Laut, Kuala Langat, Selangor, Malaysia (0242'839'N 101'33'269'E). The organic material thickness encompassed 2.5 metres in depth. Samples were taken based on two different depths having distinct degree of decomposition; Hemic and Sapric respectively. Surface samples at depth of 0-30 cm as well as subsurface samples of 40-60 cm in thickness were taken by using a McCauley peat sampler (peat auger). The surface and subsurface samples represent different types of peat material that are based on the degree of decomposition classified as Sapric and Hemic peat material. Four soil samples were collected at random from each quadrant (subunits) according to depths for each type of peat, Hemic and Sapric respectively whereby each of these four samples was a bulk of six. All of the four soil samples were then mixed homogenously to represent a single type of peat soil. These soil samples were then sealed tightly in plastic bags for transportation. Upon returning to the laboratory, a major portion of the soil samples were immediately stored at $4^{\circ} \mathrm{C}$ to preserve under their original field condition which then be used for the incubation study. A small portion of the remaining samples were air dried at $32^{\circ} \mathrm{C}$, pounded and sieved through $2 \mathrm{~mm}$ for physical and chemical characterization.

\subsection{Physical and Chemical Characterization}

Classification on the types of peat was made according to their degree of decomposition using the method of von post pressing (Parent and Caron, 1993). 
This was done at the field where fresh peat samples were first pressed on the palm. Upon pressing, extruded liquor will be expressed from the compressed organic material and the colour as well as the proportions of the extruded matter was closely observed to match on the Von Post scale for classification. The peat samples were also categorized according using the Pyrophosphate colour test (SSS, 1975).

The $\mathrm{pH}$ of the peat materials was measured potentiometrically in soil suspensions by adjusting to 1:5 Ratios of soil samples to water (Lierop and MacKenzie, 1977). The higher soil-extracting solution was used to accommodate the high water-adsorptive capacity of the peat soils (Bigger et al., 1953). The Soil Organic Carbon (SOC) was determined by using LECO analyser. Total nitrogen from the soil samples were quantified following micro-Kjeldhal method (Rutherford et al., 2008). Total $\mathrm{P}$, potassium $(\mathrm{K})$, Calcium $(\mathrm{Ca})$ and Magnesium $(\mathrm{Mg})$ were determined by dry-ashing method (Karam, 1993).

\subsection{Methods}

\subsubsection{Decomposition Study}

Mineralization of $\mathrm{P}$ in Hemic and Sapric peat was determined in a laboratory using plastic containers of 15 $\mathrm{cm}$ (diameter) $\times 10.5 \mathrm{~cm}$ (depth) with temperature regulated at $30^{\circ} \mathrm{C}$. The weight for each of the peat material with the container prior to treatment applications was recorded. Moisture content was maintained at field moist condition of $70 \%$ field capacity. As much as $800 \mathrm{~g}$ of field moist peat material were added into the container. The opening of the plastic container was covered with a piece of cloth which was secured tightly using a rubber band as to hold the cloth in place. This was also to prevent from any contamination entering the peat material in study. The samples were left to decompose aerobically for 8 weeks while the mineralization of $\mathrm{P}$ was determined by collecting soil samples at weekly interval for extractable P. The treatments applied to each type of peat material, Hemic and Sapric respectively were:

- Treatment 1: No application of lime and fertilizer (control)

- Treatment 2: Application of $20 \mathrm{~g}$ of liming material $\left(\mathrm{CaCO}_{3}\right)$ in $800 \mathrm{~g}$ of peat material

- Treatment 3: Application of $20 \mathrm{~g}$ of liming material $\left(\mathrm{CaCO}_{3}\right)$ with $5 \mathrm{~g}$ of compound fertilizer, N,P,K and $\mathrm{Mg}(12: 12: 17: 2)$ in $800 \mathrm{~g}$ of peat material
The application of lime and fertilizer were based on a recommendation for oil palm seedling stage of up to 12 months (Gillbanks, 2003).

\subsection{P-Mineralization Measurement}

The Bray-2 extract, consisting of ammonium fluoride $\left(0.03 \mathrm{M} \mathrm{NH}_{4} \mathrm{~F}\right)$ and hydrochloric acid $(0.1 \mathrm{M} \mathrm{HCl})$, was used as a soil extractant to assess $\mathrm{P}$ mineralization by quantifying the inorganic $\mathrm{P}$ in the peat material. This extracting method is recommended for neutral to acid soils and is suitable for peat soils that are very low in $\mathrm{pH}$ (Bray and Kurtz, 1945).

Two grams of fresh peat samples from each containers was used for the $\mathrm{P}$ determination. The standard method of the Bray-2 employs a 1:7 soil: solution ratio and $40 \mathrm{sec}$ extraction time. However, several modifications regarding soil: solution ratio were done by adopting a ratio of 1:10 to accommodate the high water absorptive of peat materials and was shaken for $60 \mathrm{~s}$ for extraction time. The extract was filtered through whatman No. 2 and analyzed by colorimetry method using auto analyzer.

\subsection{FTIR Spectroscopy}

After 8 weeks of incubation, the peat materials from each of the treatments were oven-dried to remove moisture in the samples. The peat samples were then analyzed by using Perkin-Elmer Spectrum 100 Spectrometer equipped with a Perkin-Elmer Universal Attenuated Total Reflectance (ATR) sampling accessory to obtain the FTIR spectra. The collection and processing of the data were performed by spectrum version 6.2.0.0055 software.

\subsection{Scanning Electron Microscopy (SEM)}

At the end of 8 weeks incubation, small amounts of peat samples were oven dried to remove the water content. Then the samples were placed onto clean support stubs which were then coated with gold using Emscope SC 500 sputter coater. These stubs were then placed into the JEOL 6400 to obtain the micrographs.

\subsection{Statistical Analysis}

Two way ANOVA was used to test the effects of soil type and treatments on extractable $\mathrm{P}$ while means of the treatments were compared using Tukey's test at 5\% level. 


\section{RESULTS}

\subsection{Physical and Chemical Characteristics of Hemic and Sapric}

The degree of decomposition for the two types of peat material used in this study can be measured by the fibres present in the peat materials (Table 1).

The unrubbed fibre in Hemic material was higher in contrast to Sapric which corroborate with the criteria mentioned in SSS (1975). The colour in Sapric material as indicated by the munsell notation has a higher value of $3 / 4$ and is much darker than Hemic material which indicated a value of $7 / 4$.

This result was also found to be similar with the characterstics determined using Von Post Scale of humification where the scale for well decomposed Sapric material was higher compared to Hemic. Sapric material achieved a scale of humification of $\mathrm{H} 8$ whereas Hemic was observed as having a degree of humification of H6 displaying a moderately high decomposed peat.

The $\mathrm{pH}$ in Hemic was higher compared to Sapric. Nevertheless, the $\mathrm{pH}$ values for both peat materials were representative for an ombrogenous oligotrophic tropical peat soil with a $\mathrm{pH}$ range in water of 3.0 to 4.5 (Andriesse, 1988).

The total content of elements such as Nitrogen $(\mathrm{N})$, Phosphorus (P), Calcium (Ca) and Magnesium (Mg) were higher in Sapric compared to the underlying Hemic material of the same peat profile.

Alternatively, the level of Potassium (K) was higher for Hemic material and the total content of $\mathrm{P}$ was the third most abundant element in these peat materials where $\mathrm{N}$ was the highest followed by $\mathrm{Mg}$.

\subsection{Mineralization of $P$}

The mineralization of $\mathrm{P}$ under control (T1) and limed (T2) condition for Hemic and Sapric peat material are given in Fig. 1. All of the treatments and peat types exhibit similar pattern in the release of extractable $\mathrm{P}$ whereby the maximum rate of release were at week 4 followed by a sharp decline at week 5 and 6 .

All of the treatments released similar amounts of extractable P at week 1 where Sapric in T1 released 105.5 $\mathrm{mg} \mathrm{kg}{ }^{-1}$ of extractable $\mathrm{P}$, followed by Hemic in $\mathrm{T} 1$ with $104.6 \mathrm{mg} \mathrm{kg}^{-1}$, Sapric in T2 at $101.6 \mathrm{mg} \mathrm{kg}^{-1}$ and Hemic in T2 with as much as $97 \mathrm{mg} \mathrm{kg}^{-1}$ of extractable $\mathrm{P}$.

During the maximum release in week 4, Hemic in T1 and T2 showed similar amounts of extractable $\mathrm{P}$ with as much as 171 and $170.6 \mathrm{mg} \mathrm{kg}^{-1}$ respectively of the treatments whereas Sapric in T2 yielded only as much as $135.4 \mathrm{mg} \mathrm{kg}^{-1}$ of extractable $\mathrm{P}$ while in $\mathrm{T} 1$ released about $160.5 \mathrm{mg} \mathrm{kg}^{-1}$ of extractable P.

After week 4, the rate of release for all treatments and peat types sharply declined where their lowest release of extractable $\mathrm{P}$ were mostly at week 7 . Sapric in T2 released only $67.2 \mathrm{mg} \mathrm{kg}^{-1}$ of available $\mathrm{P}$ while Hemic in $\mathrm{T} 2$ yielded $68.6 \mathrm{mg} \mathrm{kg}^{-1}$, followed by Hemic in $\mathrm{T} 1$ releasing as much as $69 \mathrm{mg} \mathrm{kg}^{-1}$ of extractable P. Sapric under control condition (T1) released as much as $79 \mathrm{mg}$ $\mathrm{kg}^{-1}$ on the sixth week.

When Hemic and Sapric peat materials were added with fertilizers (T3), the rate of phosphorus mineralization declined throughout 8 weeks of the incubation period (Fig. 2). Sapric peat resulted in lower mineralization rate as compared to Hemic with regards to the same treatment applied, however, both types of peat material exhibit the highest amount of available $P$ release during the second week of incubation.

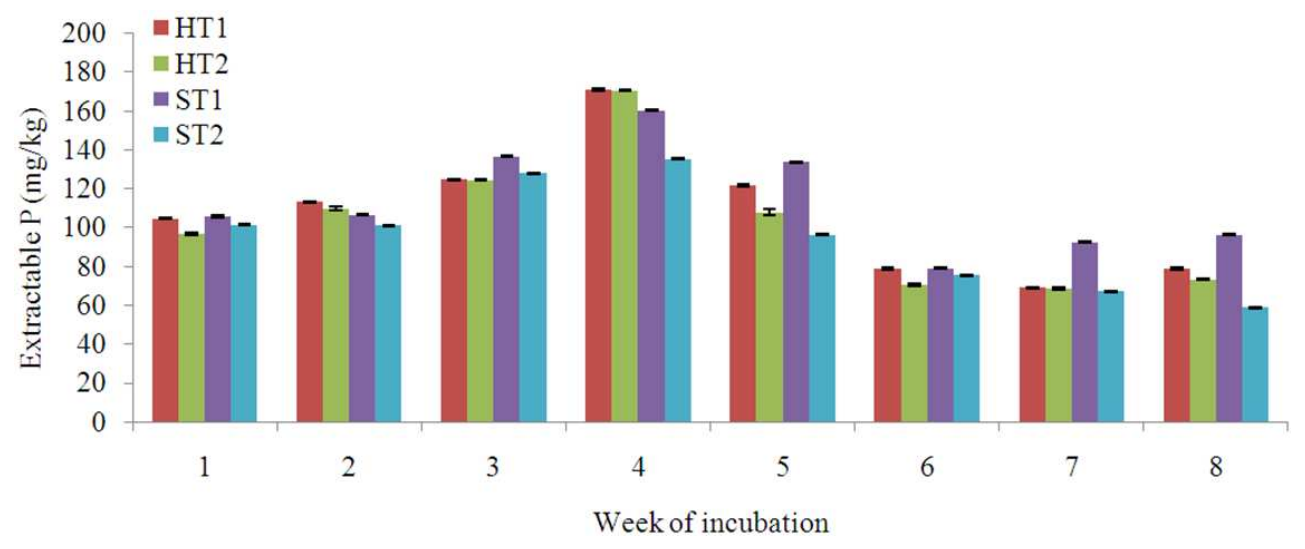

Fig. 1. Phosphorus mineralization in Hemic (H) and Sapric (S) for T1 and T2 
Ameera Abdul Reeza et al. / American Journal of Agricultural and Biological Sciences 9 (3): 321-333, 2014

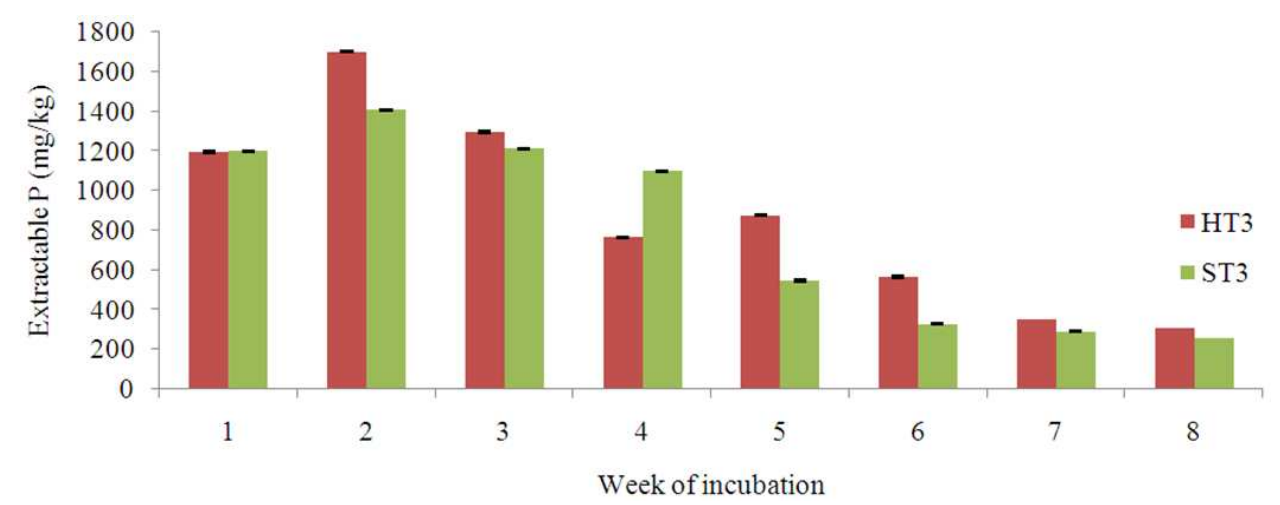

Fig. 2. Extractable $\mathrm{P}$ in Hemic $(\mathrm{H})$ and $\operatorname{Sapric}(\mathrm{S})$ for $\mathrm{T} 3$

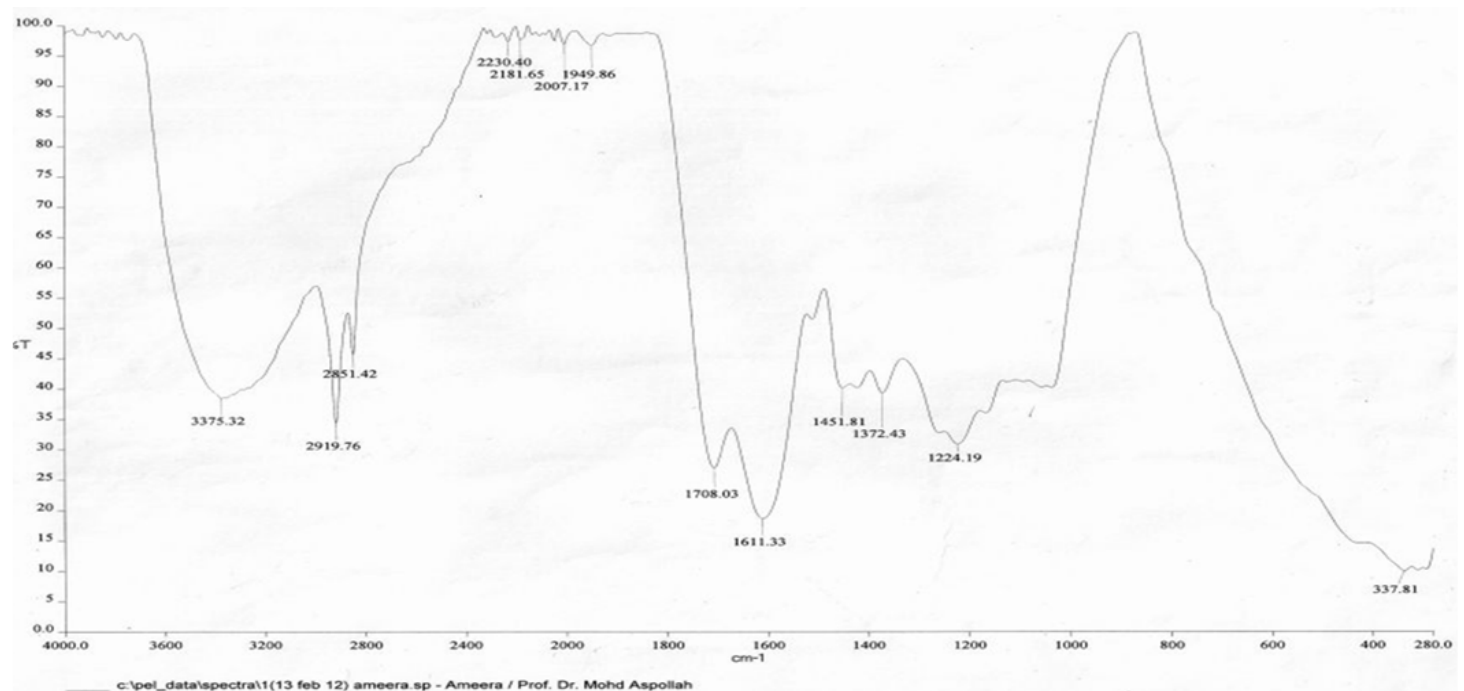

(a)

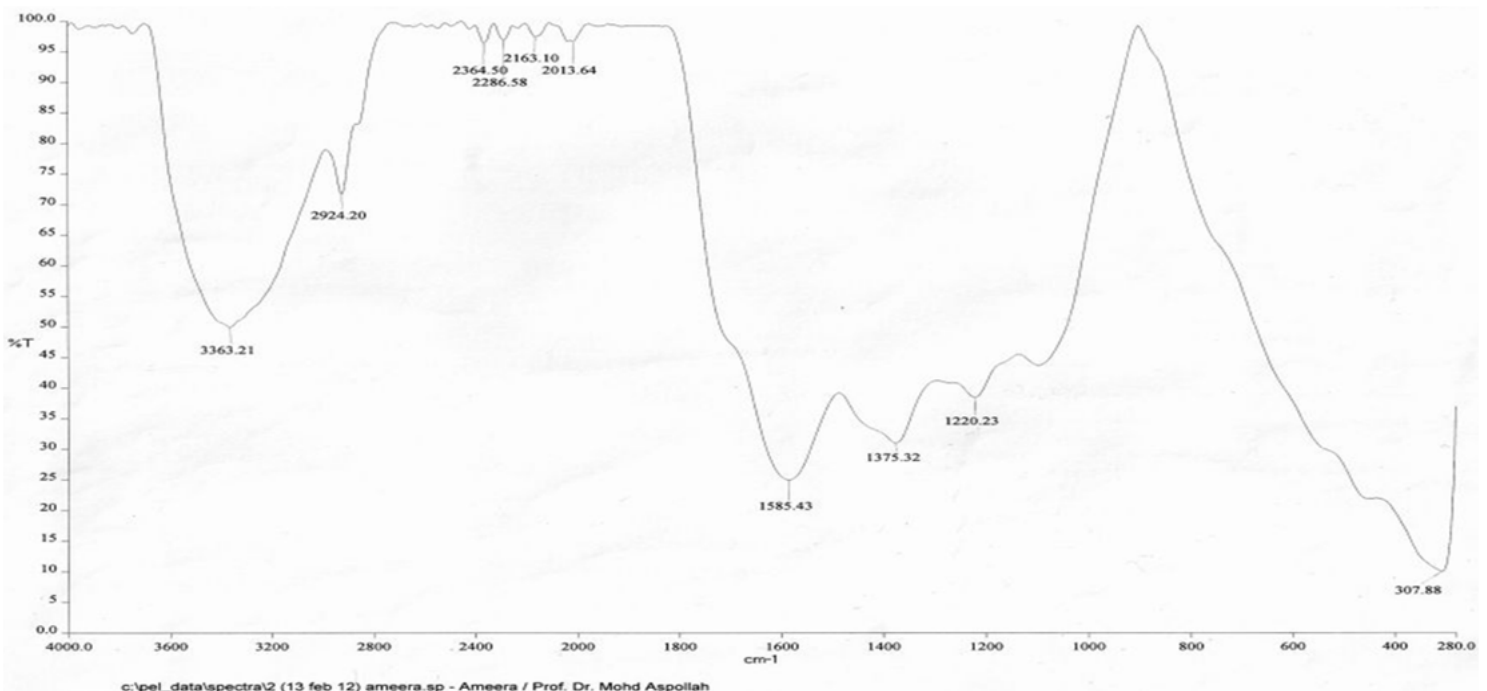

(b) 


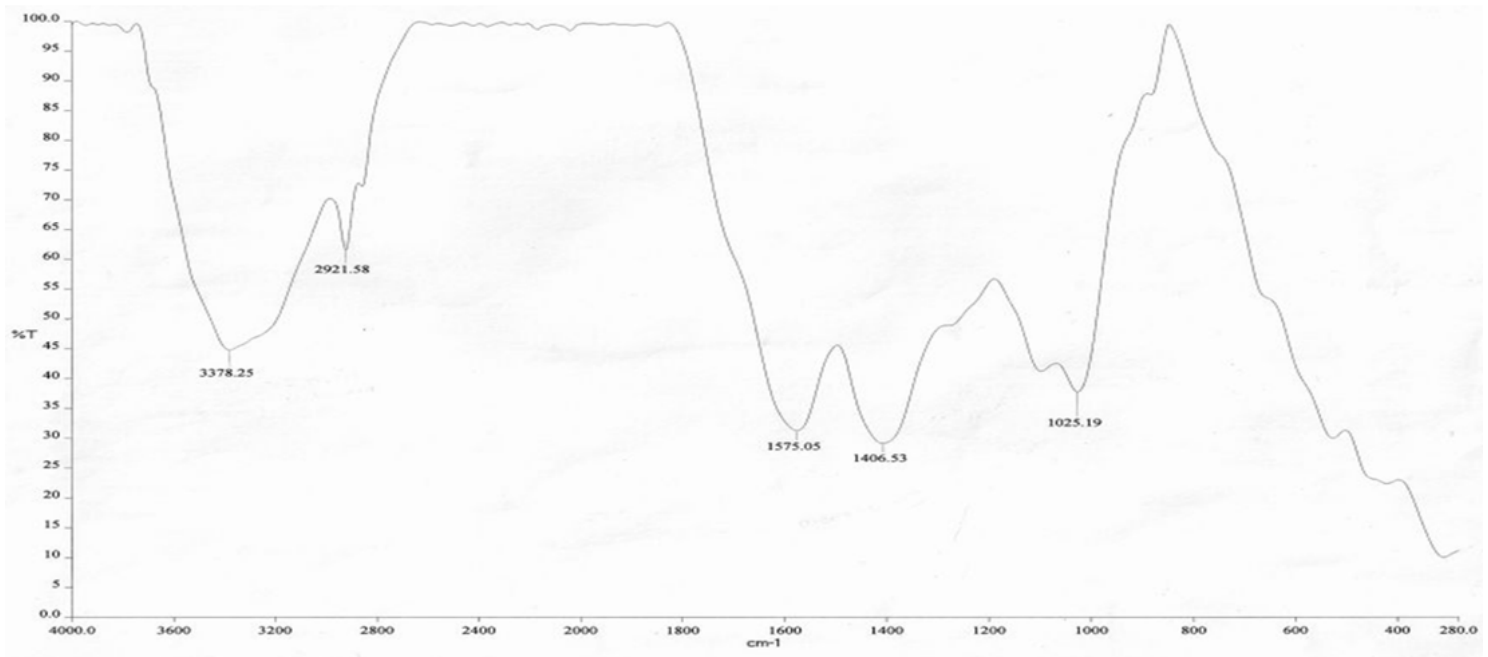

(c)

Fig. 3. Spectral data for Hemic material after 8 weeks incubation. (A) Hemic material in T1. (B) Hemic material in T2. (C) Hemic material in $\mathrm{T} 3$

Table 1. Physical and chemical characteristics of Hemic and Sapric peat material

\begin{tabular}{|c|c|c|c|}
\hline \multirow[b]{2}{*}{ Characteristics } & \multicolumn{3}{|l|}{ Type of peat } \\
\hline & Hemic & Sapric & Range \\
\hline von Post scale & H6 & $\mathrm{H} 8$ & \\
\hline (\%) unrubbed fibre & $40 \pm 2.719$ & $26.67 \pm 2.723$ & \\
\hline Munsell notation & $10 Y R 7 / 4$ & 10YR 3/4 & \\
\hline $\mathrm{pH}$ & 3.74 & 3.67 & $3-4.5^{\mathrm{a}}$ \\
\hline Total carbon $(\%)$ & $63.95 \pm 1.26$ & $62.2 \pm 1.14$ & \\
\hline Total N (\%) & 1.2 & 1.34 & $1-4 \%^{\mathrm{b}}$ \\
\hline Total P (mg/kg) & 184.3 & 224.2 & $0.01-0.5 \%^{\mathrm{b}}$ \\
\hline Total K (mg/kg) & 118.5 & 71.5 & $0.001-0.8 \%$ \\
\hline Total Ca $(\mathrm{mg} / \mathrm{kg})$ & 174.5 & 198 & $0.01-0.3 \%^{\mathrm{b}}$ \\
\hline Total Mg $(\mathrm{mg} / \mathrm{kg})$ & 748 & 892 & $0.01-0.06 \%$ \\
\hline
\end{tabular}

Source: ${ }^{a}$ Andriesse (1988); ${ }^{b}$ Lucas (1982)

It was observed that Hemic released as much as $0.17 \%$ of extractable $\mathrm{P}$ while Sapric produced about $0.14 \%$ of extractable $\mathrm{P}$ on week 2 . Extractable $\mathrm{P}$ was found to be declining from week 3 until week 8, where Hemic yielded $307 \mathrm{mg} \mathrm{kg}^{-1}$ of extractable P while Sapric with as much as $256.4 \mathrm{mg} \mathrm{kg}^{-1}$ at week 8 respectively.

At week 2, the $\mathrm{pH}$ for Hemic material rose from an initial of 3.67 to a $\mathrm{pH}$ of 6 while in Sapric material, the $\mathrm{pH}$ increased from 3.74 to a $\mathrm{pH}$ of 5.89 .

\subsection{Extractable $\mathbf{P}$ at the end of the Incubation Period}

The extractable $\mathrm{P}$ quantified at 8 weeks of incubation from different treatment applications are illustrated on Table 2. There were significant differences between treatments applied where T2 significantly contained lower amounts of extractable $\mathrm{P}$ compared to $\mathrm{T} 1$ regardless of the peat material. In contrast, the application of fertilizer in $\mathrm{T} 3$ caused a significant increase in cumulative amount of extractable $\mathrm{P}$ due to the introduction of readily available $\mathrm{P}$ from the fertilizer that can be easily extracted. There were also significant differences in the treatment effects between Hemic and Sapric material.

\subsection{FTIR Spectroscopy}

The spectra for all treatments in the two types of peat material gave few similar peak patterns (Fig. 3 and 4). The similarities were shown where all of the treatments exhibited absorption bands at around 3300 and $2900 \mathrm{~cm}^{-1}$. Both types of peat exhibit twin peaks at about 2920 and $2850 \mathrm{~cm}^{-1}$ in T1 (Fig. 3A and 4A) due to asymmetric and symmetric stretching of the $\mathrm{CH}_{2}$ groups. However, as the peat materials were added with lime and fertilizer as shown in Fig. $\mathbf{3 B}$ and $\mathbf{C}$ as well as in Fig. 4B and $\mathbf{C}$, only the asymmetric $\mathrm{CH}_{2}$ group remained in the peat materials which showed decreasing intensity with treatments.

Also, Hemic material in T1 (Fig. 3A) showed bands at 1700 and $1600 \mathrm{~cm}^{-1}$ respectively implying the presence of aliphatic and aromatic $\mathrm{C}=\mathrm{C}$ stretch but these bands were not found in T2 and T3 (Fig. 3B 
and C) and bands at $1585-1575 \mathrm{~cm}^{-1}$ were shown instead. Also, the addition of lime in T2 causing an increased in $\mathrm{pH}$ contributing to two bands appearing at 1585 and $1375 \mathrm{~cm}^{-1}$ shown at Fig. 3B indicating the presence of asymmetric (1600-1530 $\mathrm{cm}^{-1}$; strong) and symmetric (1390-1300 $\mathrm{cm}^{-1}$; medium) stretch of aliphatic nitro groups respectively (Lampman et al., 2010). Absorption at $1406 \mathrm{~cm}^{-1}$ in T3 of the Hemic in Fig. 3C material may be indicative of $\mathrm{P}-\mathrm{CH}_{2}$ (phosphines) which generally occur around 1440-1400 $\mathrm{cm}^{-1}$ as medium broad bands.

Table 2. Extractable $\mathrm{P}\left(\mathrm{mg} \mathrm{kg}^{-1}\right)$ prior to incubation and at 8 weeks of incubation for Hemic and Sapric peat material

\begin{tabular}{lll}
\hline Treatments & Hemic & Sapric \\
\hline Initial condition & $92.3 \mathrm{cA}$ & $121.7 \mathrm{cB}$ \\
T1 & $79 \mathrm{bA}$ & $96.5 \mathrm{bB}$ \\
T2 & $73.2 \mathrm{aB}$ & $58.7 \mathrm{aA}$ \\
$\mathrm{T} 3$ & $307 \mathrm{~dB}$ & $256.4 \mathrm{dA}$ \\
\hline
\end{tabular}

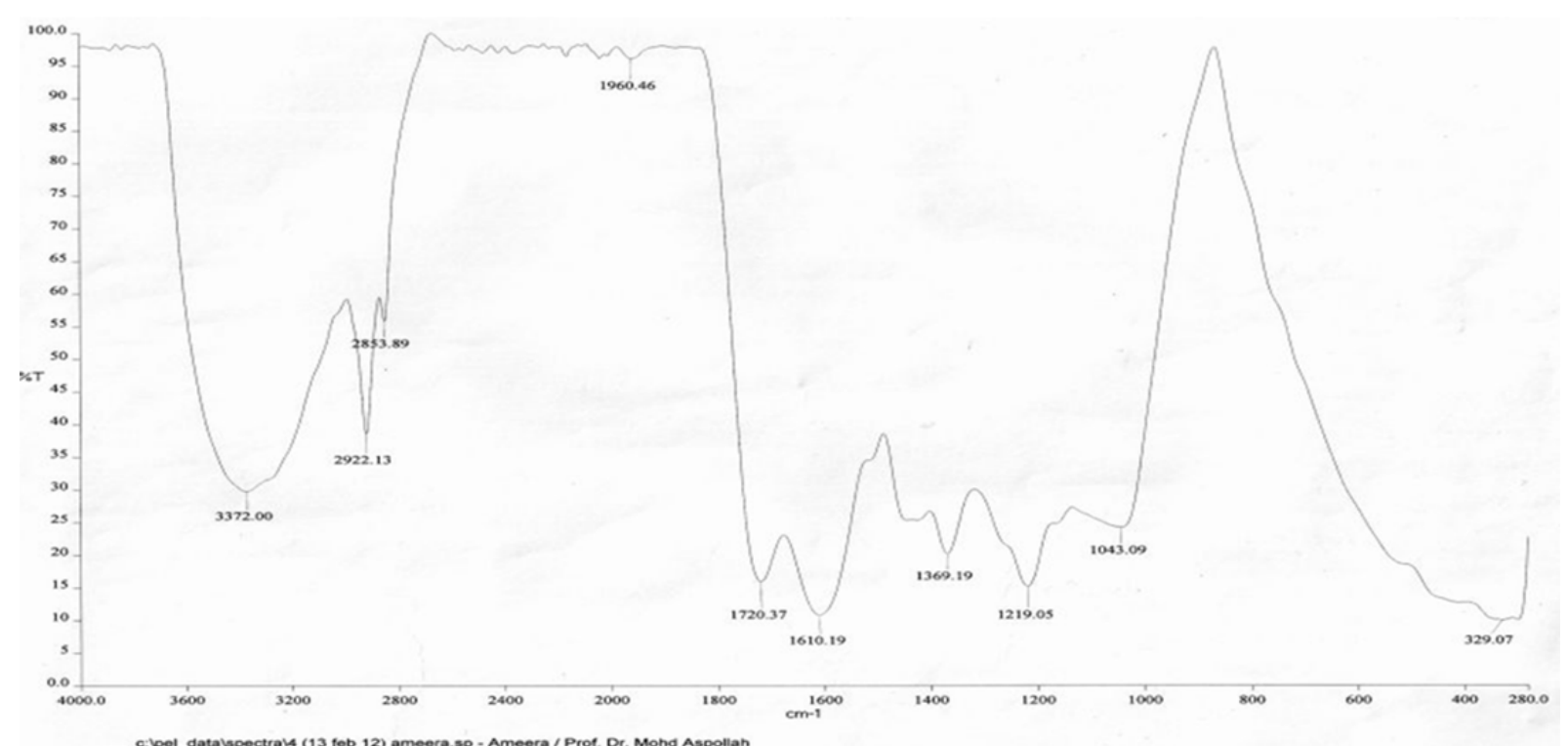

(a)

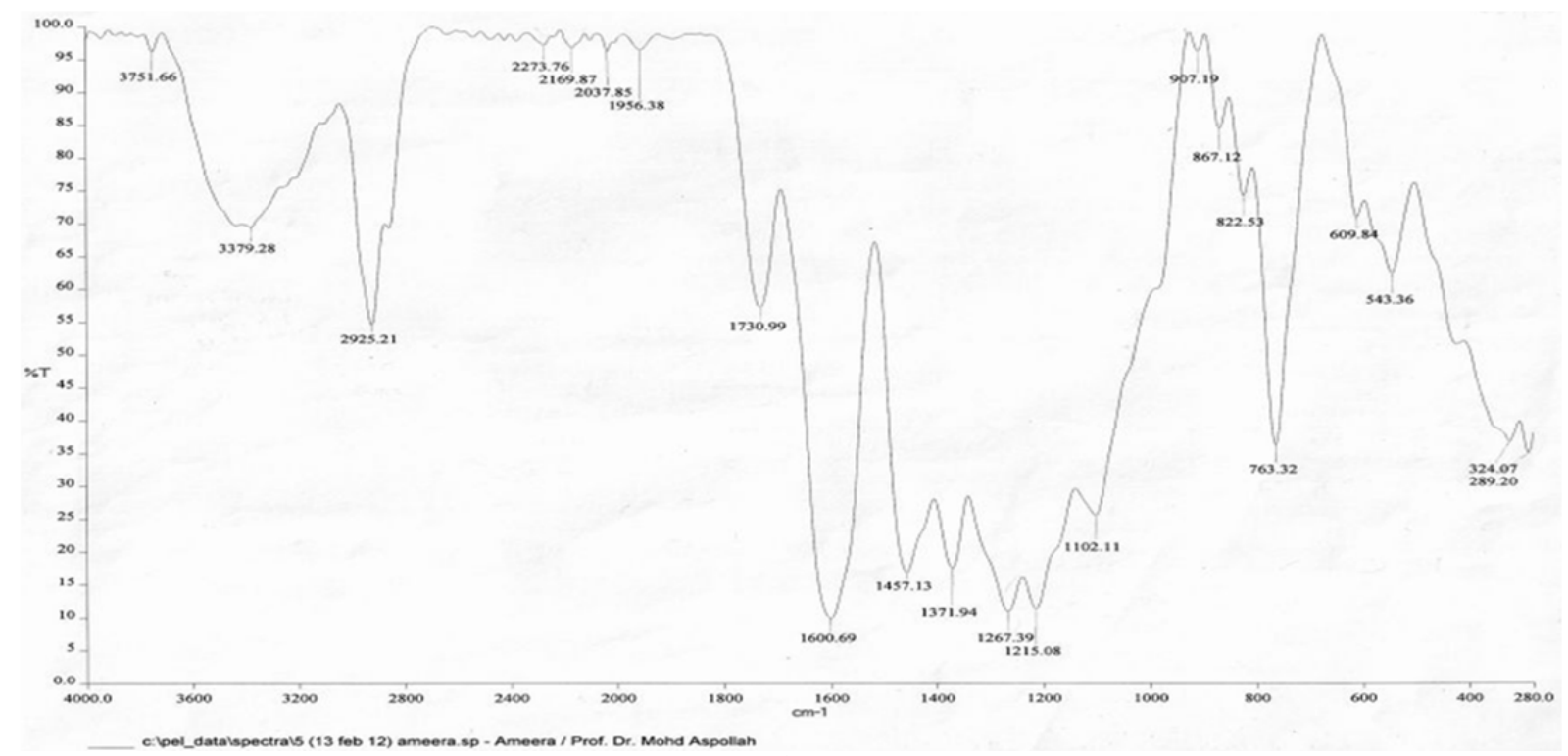

(b) 


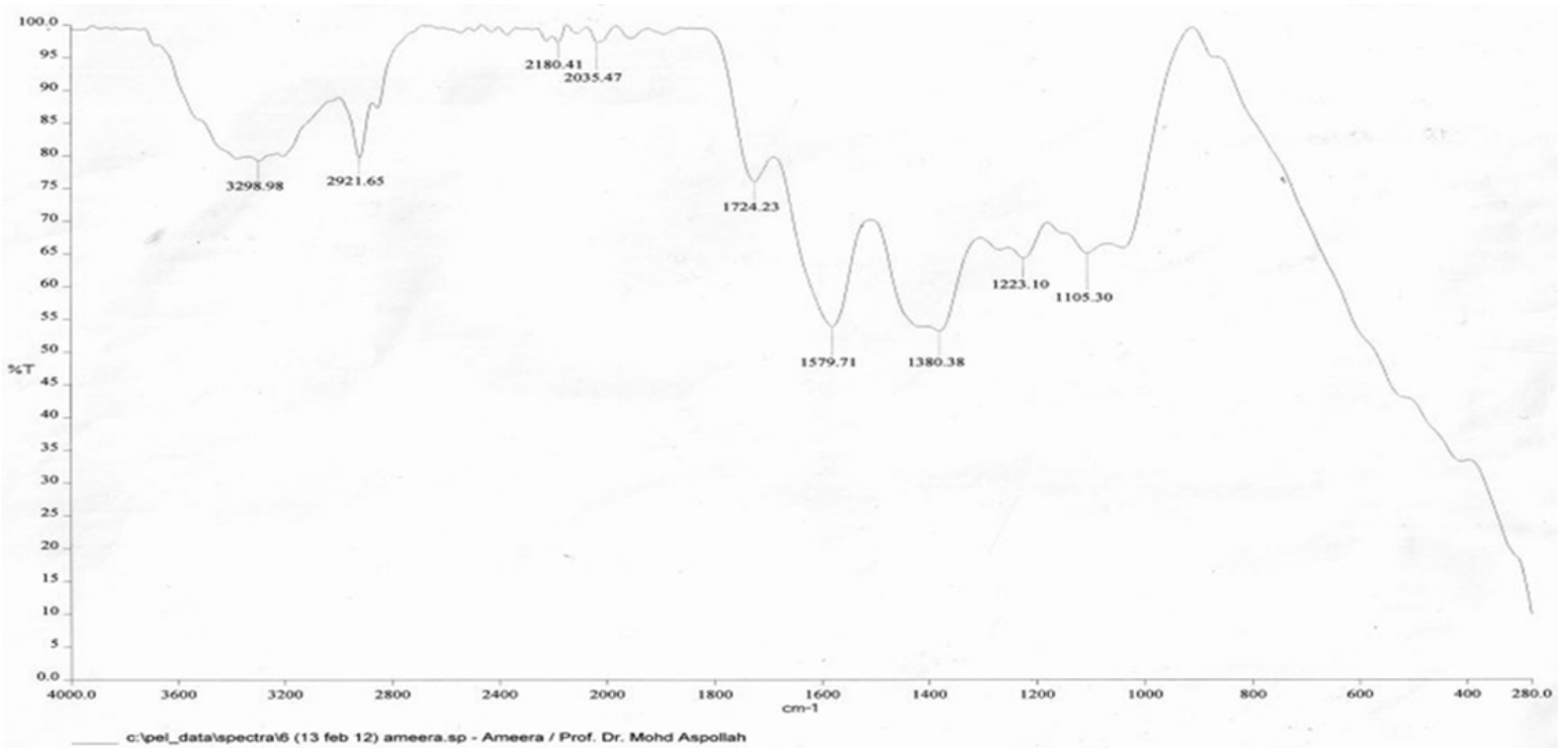

(c)

Fig. 4. Spectral data for Sapric material after 8 weeks incubation. (A) Sapric material in T1. (B) Sapric material in T2. (C) Sapric material in T3
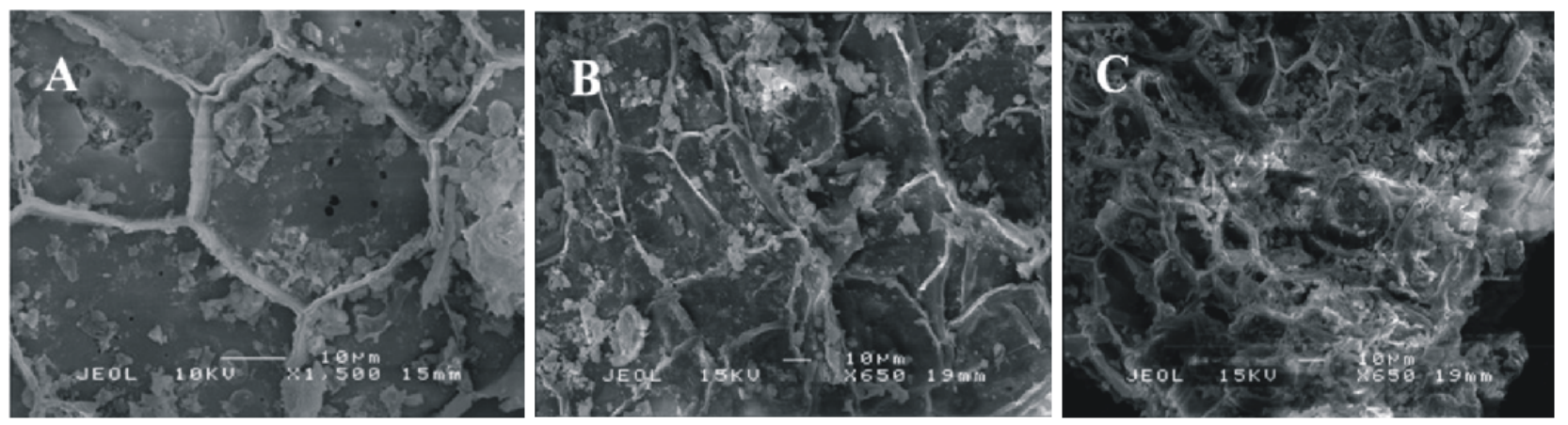

Fig. 5. SEM micrographs of Hemic material after 8 weeks of incubation. (A) Hemic material incubated under T1 (B) Hemic material incubated under T2 (C) Hemic material incubated under T3

Contrariwise to Hemic, Sapric material exhibit more adsorption bands in all treatments. It was observed that unlike Hemic material, bands at $1700 \mathrm{~cm}^{-1}$ in Sapric materials presented in Fig. 4. were still present in all 3 treatments although with decreasing intensities (1720 $\mathrm{cm}^{-1}$ in $\mathrm{T} 1,1730 \mathrm{~cm}^{-1}$ in $\mathrm{T} 2$ and $1724 \mathrm{~cm}^{-1}$ in T3) indicating a presence of carboxyl $(\mathrm{COOH})$ and/or esters (COOR) in the peat material. Diagnostic bands of $\mathrm{C}-\mathrm{O}$ stretch in esters appearing in the range of 1300 to 1000 $\mathrm{cm}^{-1}$ was shown in $\mathrm{T} 1$ and $\mathrm{T} 2$ (Fig. 4A and B) where two or more prominent bands appear between 1300-1150 $\mathrm{cm}^{-1}$ while another showing at weaker intensity between $1150-1000 \mathrm{~cm}^{-1}$. However, these bands were absent in T3. Although the bands in T3 (Fig. 4C) were similar to the range of $\mathrm{C}-\mathrm{O}$ esters, however, the patterns were different and intensities were weaker and such pattern may due to C-O stretch in secondary alcohols (1100 $\mathrm{cm}^{-1}$ ) and phenols $\left(1220 \mathrm{~cm}^{-1}\right)$.

\subsection{Scanning Electron Microscopy}

The changes in the structural component of the peat material attributed to treatment application were monitored using scanning electron microscope and are shown in Fig. 5 and 6. It can be clearly observed that the evidence of plant origin through the images of plants' cell wall structure can still be found in these peat materials. Woody plant material can also be observed by the elongated cell wall structures shown in Fig. 6D. 

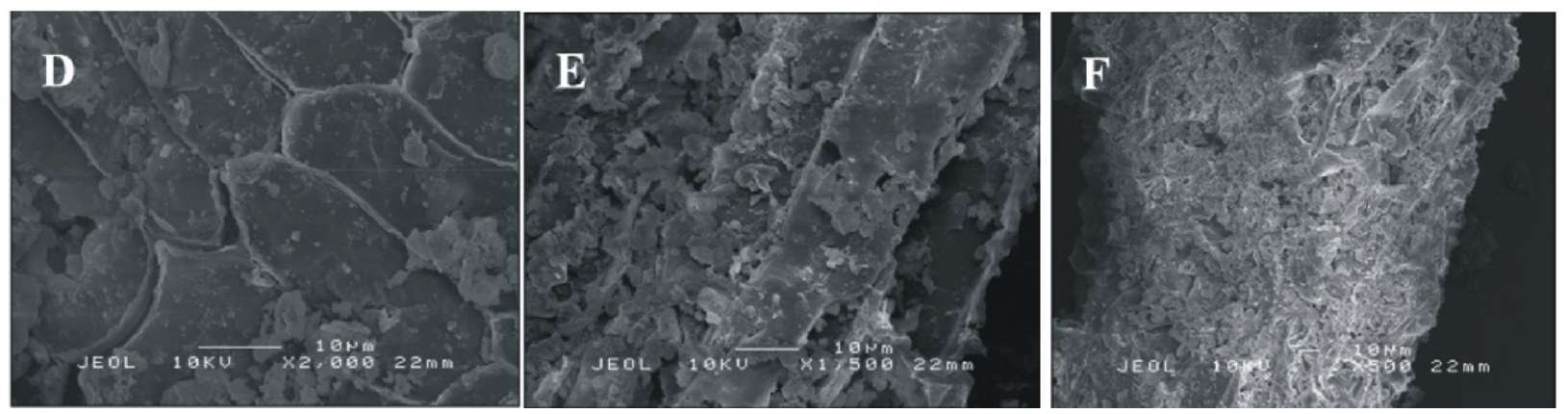

Fig. 6. SEM micrographs of Sapric material after 8 weeks of incubation. (D) Sapric material incubated under T1 (E) Sapric material incubated under T2 (F) Sapric material incubated under T3

From the images gathered, it can be understood that the addition of lime and fertilizer caused the plant cell structures to collapse and disintegrate progressively, where fertilizers in T3 causing highest rate of deterioration of the organic materials compared to lime (T2) and control (T1).

\section{DISCUSSION}

The moderately decomposed materials such as Hemic have more fibre content as compared to the well decomposed Sapric material due to the advanced mineralization in Sapric where most fibres have been decomposed and converted to other components by microbes, leaving the more resistant materials remaining in the soil forming humic material which explains the darker colour of the Sapric material achieving a scale of humification of $\mathrm{H} 8$ indicating very highly decomposed peat where most of the material are amorphous and exhibit very indistinct plant structure after squeezing between fingers. As for Hemic, a scale of H6 implies that_plant structures are more distinct even after the material has been squeezed.

The extreme acidity in peat materials is a typical characteristic for organic soils due to the presence of organic compounds such as humic substances consisting of humic acids, fulvic acids and humin as well as abundance of $\mathrm{H}^{+}$ions produced by microorganisms during decomposition. Also, such similar $\mathrm{pH}$ in Sapric peat material was also found in a lowland tropical peat swamp forest in Sarawak (Satrio et al., 2009a). The higher nutrient content in Sapric peat material was attributed based on the fact that since the upper-most layer of the peat is well-decomposed and thus more aerated, hence it has undergone advanced mineralization. The total content of $\mathrm{P}$ in the present peat materials corroborated with the range of total $\mathrm{P}$ content in peat reported by Kanapathy (1976), where the level of $\mathrm{P}$ in such soils are still quite low for plant requirement comprising only around $0.006-0.02 \%$ compared to mineral soils such as Mollisols where values of 750-830 $\mathrm{mg} \mathrm{kg}{ }^{-1}$ of total $\mathrm{P}$ can be found (Lopez-Hernandez and Sequera, 2012). Nonetheless, the total P in Sapric (224.2 $\mathrm{mg} \mathrm{kg}^{-1}$ ) was found to be very similar to the undisturbed peat swamp forest in Sarawak (200 mg $\mathrm{kg}^{-1}$ ) as documented by Satrio et al. (2009b).

It was observed that the introduction of lime by increasing the $\mathrm{pH}$ of the peat material from 3.67 (Sapric) and 3.74 (Hemic) to a pH of 6.5 at week 6 did not improved the release of P. Instead, peat materials that were under controlled condition (T1) released higher amounts of extractable P compared to the limedtreated peat soils (T2). Such condition can be seen clearly between $\mathrm{T} 1$ and $\mathrm{T} 2$ in Sapric material. The increase in extractable $\mathrm{P}$ during the first 4 weeks might be attributed to the decomposition process in the organic matters of peat material which resulted in the production of organic acids competing with $\mathrm{P}$ for the adsorption onto soil particles.

As a consequence, the presence of organic acids reduces $\mathrm{P}$ sorptivity onto soil colloids (Hue, 1991) thereby increasing the availability of $\mathrm{P}$ to be extracted which explains the ascending pattern of extractable $\mathrm{P}$ during week 3 and 4. However, according to Guppy et al. (2005), the decline in P sorption are not attributed to the competition effects between the breakdown product of organic matter decomposition, but rather due to the result of $\mathrm{P}$ release from the organic matter that was not accounted when determining the reduction in $\mathrm{P}$ sorption. Although the amount of extractable $\mathrm{P}$ were similar between the two treatments, however the $\mathrm{pH}$ differ significantly where $\mathrm{T} 1$ achieved a $\mathrm{pH}$ of 4.2 and $\mathrm{T} 2$ reached a $\mathrm{pH}$ of 5.8 . 
The lower values of extractable $\mathrm{P}$ observed in $\mathrm{T} 2$ indicated that the effect of liming may cause a reduction in extractable $\mathrm{P}$ in Sapric peat material. Although the $\mathrm{pH}$ in $\mathrm{T} 2$ was increased from about 3.67 to a $\mathrm{pH}$ of 6.5 as to alleviate the acidity of the peat, yet it resulted in the suppression of $\mathrm{P}$ release. According to previous studies done by Holford (1983) as well as by Barrow (1972) reported that liming to a $\mathrm{pH}$ of 6.0 resulted in the increase of phosphate sorptivity in the soil due to very large increases in the concentration of calcium that occurred especially in undrained pots used for soil incubation similar to the present study. This caused the $\mathrm{P}$ to be sorbed to calcium forming $\mathrm{Ca}-\mathrm{P}$ complexes resulting to less available form of $\mathrm{P}$ to be extracted.

The high amounts of $\mathrm{P}$ extracted during week 2 and 3 created a condition where the soil is rich in soluble P. Such condition triggered an increase in the activity of microorganisms to incorporate $\mathrm{P}$ into their biomass. As a result, the amount of extractable $\mathrm{P}$ in these peat materials reduced justifying the descending pattern during week 5 and 6. While the amount of extractable $\mathrm{P}$ declined at week 5 and 6 , the peat material is now depleting in $\mathrm{P}$ supply, thus stimulating for the mineralization of organic $\mathrm{P}$ to replenish the diminishing amount of $\mathrm{P}$ in the soil thereby explaining the slight increasing pattern at week 7 and 8 . The significant differences in the amount of $\mathrm{P}$ extracted between Hemic and Sapric peat material is an indicative that distinct types of peat material result in different amounts of $\mathrm{P}$ release upon the application of lime and fertilizer.

According to Busman et al. (2002), the range of $\mathrm{pH}$ for the highest $\mathrm{P}$ availability is between 5.5 and 7.0, a condition similar to the present study observed in week 2 of the incubation study for T3. A major portion of the $\mathrm{P}$ extracted comes from fertilizer application where it is readily available to plant due to its high solubility. This finding is in agreement with the works of Wright et al. (2012) where most of the applied fertilizer P ends up in the plant available or solution $\mathrm{P}$ pool where it is directly available for crop uptake.

Such availability of $\mathrm{P}$ did not prolonged due to the high solubility of the $\mathrm{P}$ extracted, thus it can react easily with the exchangeable basic cations such as calcium causing it to be temporarily unavailable for plants (Wright et al., 2012). The addition of lime with fertilizer application in $\mathrm{T} 3$ resulted in the increase of the concentration of calcium cations. Also, according to Brady and Weil (2002), when water soluble phosphorus such as fertilizers are added to the soils, they will be fixed with the soil colliods and consequently forming highly-insoluble compounds with time. Such condition eventually reduces the persistence of the readily available $\mathrm{P}$ after the application of fertilizer thus explaining the declining pattern of extractable $\mathrm{P}$ observed throughout the incubation period.

Another probable reason for the diminishing amount of extractable $\mathrm{P}$ all through the period of incubation might be attributed to the population of the microorganisms that are actively incorporating the soluble $\mathrm{P}$ from the fertilizer application into their biomass. It was observed that the $\mathrm{pH}$ of the peat material for both Hemic and Sapric was near neutral (6.5-6.7) after week 3 onwards, a suitable condition for microbes to thrive on the soil. Thus, the highly soluble $\mathrm{P}$ during the initial weeks (week 1 and 2) became less available to be extracted.

The broad band of about $3300 \mathrm{~cm}^{-1}$ from the FTIR spectral data was shown to be attributed to the $\mathrm{O}-\mathrm{H}$ stretching of hydrogen bonded hydroxyl groups while band at around $2900 \mathrm{~cm}^{-1}$ generally ascribed to the asymmetric stretching of aliphatic $\mathrm{C}-\mathrm{H}$ groups (methylene). In peat samples, the presence of hydrogen bonded $\mathrm{O}-\mathrm{H}$ groups may due to the occurrence of cellulose in the sample (Cocozza et al., 2003) while the aliphatic $\mathrm{CH}_{2}$ groups may imply to the presence of fats, wax and lipids (Niemeyer et al., 1992; Cocozza et al., 2003).

Although these two bands were present in all treatments, however, their intensities decreased as the peat materials were added with lime and fertilizer treatments in T2 and T3 (Fig. $\mathbf{4 B}$ and $\mathbf{C}$ ) compared to T1 (Fig. 4A). This may indicate that the cellulotic and lipid properties in the peat materials are declining due to more rapid mineralization in $\mathrm{T} 2$ and $\mathrm{T} 3$ attributed to lime and fertilizer comparing to $\mathrm{T} 1$. Other than that, the decreasing intensities may also suggest that higher $\mathrm{pH}$ values of the material as a result of liming application in T2 and T3 (Fig. 4B and C) may have reduced the amount of carboxylic acids forming carboxylate.

The twin peaks at about 2920 and $2850 \mathrm{~cm}^{-1}$ in T1 are typically found in peat samples as documented by Artz et al. (2008) indicating the presence of fats, wax and lipid properties. The dissapearance of band at $2850 \mathrm{~cm}^{-1}$ when lime was added into the peat materials may be attributed to the transformation from refractory aliphatic compounds to simpler moieties (Cocozza et al., 2003).

The shifting of these bands to the right in $\mathrm{T} 2$ and T3 of Hemic material may be due to the changing of 
functional groups from $\mathrm{C}=\mathrm{C}$ to $\mathrm{N}-\mathrm{H}$ or aliphatic nitro compounds (Lampman et al., 2010). Such condition may be possible especially in $\mathrm{T} 3$ where fertilizer containing nitrogen were added into the peat material. Also, the higher amounts of absorption bands in Sapric material showed that that the two types of peat may behave differently upon the application of treatments. The lesser amount of such bands in Hemic material may imply that although this peat material is also as acidic as Sapric, however, the buffering capacity in Hemic material is lower compared to Sapric resulting in much lesser carboxylic acids being retained in the peat material and thus resulting in the absence of the bands. Such result corroborated with the findings reported by Gondar et al. (2005).

The use of FTIR spectra assist in increased apprehension on the behaviour of the peat materials upon agricultural practices by understanding the changes in their functional groups brought upon the application of lime and fertilizers which in turns relate to the reactivity of the peat materials to adsorb and hold nutrients for the uptake of plants since nutrients are held by these functional groups particularly phenolic and carboxylic acids.

The changes in the cell structures of the peat materials upon the addition of lime and fertilizer application provide justification that decomposition has taken place in these peat materials. The higher degree of degradation in the plant's cell for T2 and T3 are mostly attributed to microbial activity that caused the rupturing of the cell structures in order to obtain carbon for energy for the microbes to sustain in these peat materials. However, the use of SEM has yet to show any structural discrepancies between the two types of peat material since both of these organic material are of the same parental vegetation.

\section{CONCLUSION}

It is important to understand that Hemic and Sapric peat material used in this study were originated from the same parent vegetation where they were taken from the same location. However, they represent different types of peat material due to having distinct degrees of decomposition since they were collected from separate depths. The mineralization of phosphorus from Hemic and Sapric followed a similar pattern. However, the rate of release differed between the two types of peat material. Although the addition of lime caused an increased in the $\mathrm{pH}$ of the peat materials, such changes did not significantly improved the amount of phosphorus being extracted. However, micrographs obtained from SEM showed that decomposition continued especially in T2 and T3 which led to the degradation of the structural vegetal matter. The application of fertilizer in T3 increased the amount of extractable phosphorus for both types of peat materials but rapidly declined throughout 8 weeks of the incubation period. Spectral data from FTIR showed that the absorption bands were the weakest in T3 with respect to the peaks that were similar with other treatments, however, different bands were shown at lower frequencies.

This study may provide better understanding on the behaviour of Hemic and Sapric peat material upon the addition of lime and fertilizers in physical as well as chemical aspects. Such information are useful in predicting changes in the nutrient dynamics of peat soils that are brought upon by anthropogenic inputs as to facilitate in better planning and application of lime and fertilizers.

\section{REFERENCES}

Andriesse, J.P., 1988. Nature and Management of Tropical Peat Soils. 1st Edn., Food and Agriculture Org., ISBN-10: 9251026572 pp: 165.

Artz, R.R.E., S.J. Chapman, A.H.J. Robertson, J.M. Potts and F.L. Defargec et al., 2008. FTIR spectroscopy can be used as a screening tool for organic matter quality in regenerating cutover peatlands. Soil Biol. Biochem., 40: 515-527. DOI: 10.1016/j.soilbio.2007.09.019

Barrow, N.J., 1972. Influence of solution concentration of calcium on the adsorption of phosphate, sulphate and molybdate by soils. Soil Sci., 113: 175-180. DOI: 10.1097/00010694-197203000-00005

Bigger, T.C., J.F. Davis and K. Lawton, 1953. The behaviour of applied phosphorus and potassium in organic soil as indicated by soil tests and the relationship between soil tests, green-tissue tests and crop yields. Soil Sci. Society Am. Proc., 17: 279283.

DOI: 10.2136/sssaj1953.03615995001700030023x

Brady, N.C. and R.R. Weil, 2002. The Nature and Properties of Soils. 14th Edn., Prentice Hall, USA., ISBN-10: 013227938X, pp: 980.

Bray, R.H. and L.T. Kurtz, 1945. Determination of total, organic and available forms of phosphorus in soils. Soil Sci., 59: 39-46.

Busman, L., J. Lamb, G. Randall, G. Rehm and M. Schmitt, 2002. The nature of phosphorus in soils. Regents of the University of Minnesota. 
Cocozza, C., V. D’Orazio, T.M. Miano and W. Shotyk, 2003. Characterization of solid and aqueous phases of a peat bog profile using molecular fluorescence spectroscopy, ESR and FT-IR and comparison with physical properties. Organic Geochem., 34: 49-60. DOI: 10.1016/S0146-6380(02)00208-5

Gillbanks, R.A., 2003. Standard Agronomic Procedures and Practices. In: Oil Palm: Management for Large and Sustainable Yields, Fairhaust, T. and R. Hardter (Eds.), Potash and Phosphate Institute, Singapore, ISBN-10: 9810484852, pp: 115-150.

Gondar, D., R. Lopez, S. Fiol, J.M. Antelo and F. Arce, 2005. Characterization and acid-base properties of fulvic and humic acids isolated from two horizons of an ombrotrophic peat bog. Geoderma, 126: 367-374. DOI: 10.1016/j.geoderma.2004.10.006

Guppy, C.N., N.W. Menzies, P.W. Moody and F.P.C. Blamey, 2005. Competitive sorption reactions between phosphorus and organic matter in soil: A review. Soil Res., 43: 189-202. DOI: 10.1071/SR04049

Gurmit, S., Y.P. Tan, C.V.R. Padman and F.W. Lee, 1987. Experiences on the cultivation and management of oil palms on deep peat in United Plantations Berhad. Planter, 63: 143-157.

Haberhaeur, G., B. Rafferty, F. Strebl and M.H. Gerzabek, 1998. Comparison of the composition of forest soil litter derived from three different sites at various decompositional stages using FTIR spectroscopy. Geoderma, 83: 331-342. DOI: 10.1016/S0016-7061(98)00008-1

Haynes, R.J., 1982. Effects of liming on phosphate availability in acid soils. Plant Soil, 68: 289-308. DOI: 10.1007/BF02197935

Holford, I.C.R., 1983. Effects of lime on phosphate sorption characteristics and exchangeable and soluble phosphate in fifteen acid soils. Australian J. Soil Res., 21: 333-342. DOI: 10.1071/SR9830333

Hue, N.V., 1991. Effects of organic acids/anions on $\mathrm{P}$ sorption and phytoavailability in soils with different minerologies. Soil Sci., 152: 463-471.

Jordan, S., S. Velty and J. Zeitz, 2007. The influence of degree of peat decomposition on phosphorus binding forms in fens.

Kanapathy, K., 1976. Fertilizer requirement on peat soils. Malaysian Agric. J., 50: 292-307.

Karam, A., 1993. Chemical Properties of Organic Soils. In: Soil Sampling and Methods of Analysis, Carter, M.R. (Ed.), Lewis Publishers, Boca Raton, ISBN10: 0-87371-861-5, pp: 459-471.
Lampman, G.M., D.L. Pavia, G.S. Kriz and J.R. Vyvyan, 2010. Spectroscopy. 4th Edn., Brooks/Cole Cengage Learning, United States, pp: 656.

Lewandowski, A., 2002. Soil scientist.

Lickacz, J. and D. Penny, 2001. Soil organic matter.

Lim, K.H., S.S. Lim, F. Parish and R. Suharto, 2012. RSPO Manual on Best Management Practices (BMPs) for Existing Oil Palm Cultivation on Peat. 1st Edn., RSPO, Kuala Lumpur.

Lopez-Hernandez, D. and D. Sequera, 2012. Phosphorus biogeochemical cycling in a sugar cane agroecosystem. Am. J. Agric. Biol. Sci., 7: 473-481. DOI: 10.3844/ajabssp.2012.473.481

Lucas, R.E., 1982. Organic soils (Histosols). Formation, distribution, physical and chemical properties and management for crop production. Michigan State University Agricultural Experiment station.

Niemeyer, J., Y. Chen and J.M. Bollag, 1992. Characterization of humic acids, composts and peat by diffuse reflectance fourier-transform infraredspectroscopy. Soil Sci. Society Am. J., 56: 135-140.

Parent, L.E. and J. Caron, 1993. Physical Properties of Organic Soils. In: Soil Sampling and Methods of Analysis, Carter, M.R. (Eds.), Lewis Publishers, Boca Raton, ISBN-10: 0-87371-861-5, pp: 441-458.

Rutherford, P.M., W.B. McGill, J.M. Arocena and C.T. Figueiredo, 2008. Total Nitrogen. In: Soil Sampling and Methods of Analysis. Carter, M.R. and E.G. Gregorich (Eds.), CRC Press Taylor and Francis Group, United States, pp: 239-250.

Satrio, A.E., G. Seca, O.H. Ahmed and N.M.A. Majid, 2009a. Effect of precipitation fluctuation on soil carbon storage of a tropical peat swamp forest. Am. J. Applied Sci., 8: 1484-1488. DOI: 10.3844/ajassp.2009.1484.1488

Satrio, A. E., S. Gandaseca, O. H. Ahmed and N.M. A. Majid, 2009b. Effect of logging operation on soil carbon storage of a tropical peat swamp forest. Am. J. Environ. Sci., 5: 748-752. DOI: 10.3844/ajessp.2009.748.752

SSS, 1975. Soil Taxonomy: A Basic System of Soil Classification for Making and Interpreting Soil Surveys. 1st Edn., United States Department of Agriculture, John Wiley and Sons, United States, ISBN-10: 0-471-8009-0, pp: 754.

Strack, M., 2008. Peatlands and Climate Change. 1st Edn., International Peat Society, Finland, ISBN-10: 9529940114, pp: 223. 
Tayeb, M.D., 2005. Technologies for Planting Oil Palm on Peat. 1st Edn., Malaysian Palm Oil Board, Kuala Lumpur, ISBN-10: 9679611132, pp: 84.

Lierop, W.M.V. and A.F. MacKenzie, 1977. Soil pH measurement and its application to organic soils. Canad. J. Soil Sci., 57: 55-64. DOI: 10.4141/cjss77-008

Verhoeven, J.T.A. and H.H.M. Arts, 1987. Nutrient dynamics in small mesotrophic fens surrounded by cultivated lands. II $\mathrm{N}$ and $\mathrm{P}$ accumulation in plant biomass in relation to the release of inorganic $\mathrm{N}$ and $\mathrm{P}$ in the peat soil. Oecologia, 72: 557-561.
Verhoeven, J.T.A., E. Maltby and M.B. Schmitz, 1990. Nitrogen and phosphorus mineralization in fens and bogs. J. Ecol., 78: 713-726.

Wright, A.L., E.A. Hanlon and J.M. McCray, 2012. Fate of phosphorus in everglades agricultural soils after fertilizer application. Institute of Food and Agricultural Sciences, University of Florida.

Yli-Halla, M. and I. Lumme, 1987. Behaviour of certain phosphorus and potassium compounds in a sedge peat soil. Silva Fennica, 21: 251-257. 